\title{
Why say no to innovation? Evidence from industrial SMEs in European Union
}

\author{
Nuno Carvalho ${ }^{1 \star}$ and Zornitsa Yordanova ${ }^{2}$
}

\begin{abstract}
This paper aims at presenting the results from a research on the reasons why more than 50\% of the small and medium size enterprises (SMEs) in European Union (EU) are non-innovative. The paper intends to find out which are the specific factors that influence the percentage of non-innovative industrial SMEs, considering that SMEs are the main stakeholders and target group of EU funds and policies, and industry is the main direction for economic development.
\end{abstract}

The study employs a cross-sectional study and linear regressions. The findings after applying the research methodology show some already known factors that obstruct SMEs innovation performance like lack of internal finance and little market competition. However, the main contribution of the research is the finding that a low market demand does not contribute to an increase in the percentage of non-innovative enterprises.

As a conclusion, all the measures and EU programs for boosting market demand for the purposes of increasing the number of innovative enterprises would be useless.

Keywords: innovation; SME; industry; European Union; non-innovative enterprises.

Submitted: May 10 $0^{\text {th }}, 2017$ / Approved: April $9^{\text {th }}, 2018$

\section{Introduction}

It is unbelievable that more than $50 \%$ of all SMEs in EU are non-innovative. That sounds strange and provokes a lot of questions, especially when innovations are amongst the main focuses of EU members' policies and efforts and so much money has been spent on that. It becomes more and more interesting after the McKinsey research showing that more than $94 \%$ of the managers are not satisfied with their own enterprises innovation performance (Bamford and Ernst 2002). And why is that after all?

Many researchers summarize that, basically, there are two fundamental aspects that can be directly used for achieving economic viability and competitiveness on macro level: to develop countries' potential to generate innovations and to develop some mechanisms of these countries to adopt innovations (Janger et al. 2017; Zhelev 2014; Bentivoglio, Giampietri, and Finco 2016). Obviously, improving and boosting a country's innovativeness means improving the country's enterprises' innovativeness. For EU, the most central and essential goal is to achieve leadership in its position among the other countries outside the Union, i.e. to outrun the main economic actors in the world (EUROPEAN UNION 2007). And for achieving that one and unique goal, EU clearly and logically states that innovation is the most influential and reliable tool for leading their economy to the first place in the world as well as it is crucial for achieving competitiveness (Comission 2017). Following that belief and vision, EU has many strategies, policies and stimulations to its member countries so they to perceive and implement that model perspective within their internal economic models and policies. By doing this, EU ensures the achievement of general good performance on innovation indicators that are set as key performance indicators (KPIs). The KPIs in terms of achieving that proper purpose of the EU, i.e. to become the leading economy in the world are all related to its country members' performance and especially innovation development. The proper KPIs are developed and measured by different models like European Innovation Scoreboard, Global Innovation Index; World Economic Forum, The Global Competitiveness Report; The Innobarometer. An evidence for that focus is the European strategy for employment and growth - Europe 2020 Strategy - that has given the shape to the economic policy of EU and its Member States and where innovation has a central role (Di Cataldo and Rodriguez-Pose 2017; Elert, Henrekson, and Stenkula 2017; Lewandowska and Weresa 2016). By boosting innovation, Europe can work on its priorities in a long-term perspective (Bailey 2014) and a particular metric for successful implementation of EU policies is the level of investment in research and development (R\&D). The Union sets a rule to achieve and sustain a level of investment in $\mathrm{R} \& \mathrm{D}$, from both public and private organizations, around 3\% of gross domestic product (GDP). As the R\&D expenditure in Europe in 2010 was below $2 \%$, while in the USA reached $2.6 \%$, and Japan $3.4 \%$ it's possible to conclude that there is still a long way to go, even because in 2016 the average result for EU was only slightly over 2\% (Eurostat 2016).

Recently and during the last 20 years, EU has implied many mechanisms, policies, funding opportunities and monitoring so to achieve an increase in enterprises' innovativeness. European Union has spent a lot of money and efforts on that initiative (Chobanova 2016) and has transformed its identity by pursuing that goal and the metrics for innovation development that it sets all the time (Fougère, Segercrantz, and Seeck 2017).

At the end, between 2014 and 2020, more than 190 billion euros will have been spent for enterprises' innovations via Horizon 2020 and European Structural and Investment Funds, but still almost 50\% of EU enterprises are non-innovative (Eurostat 2017).

(1) Economics Faculty, University of Coimbra, Coimbra, Portugal

(2) Industrial Business Department, University of national and world economy, Sofia, Bulgaria

Corresponding author: nunomcarv@gmail.com 
The research is provoked exactly by that disproportion and contradiction between all EU efforts on boosting enterprises' innovativeness and the results that clearly indicate that most of the enterprises are non-innovative. The role of industrial policies is also an important factor for the innovativeness of enterprises (Khan, Lew, and Akhtar 2016) in the scope of the study. The research aims at revealing what are the factors that influence enterprises in their decision and existence as non-innovative. The main focus is put on financial constraints, market competition and market demand. The proper research question is: Do financial constraints, market competition and market demand influence the percentage of non-innovative enterprises?

For answering the research question, a cross sectional analysis (macro level) is undertaken, using data from EU countries. The data covers industrial SMEs from EU's country members.

It is expected that this research may contribute to foster public policies that may aim at promoting the transition of non-innovative to innovative SMEs because the importance of effective public policies in the promotion of innovation is unquestionable (Carvalho, Carvalho, and Nunes 2015; Carvalho and Lourenço 2017).

The paper could be of interest to both science and practitioners. It concerns governmental and business issues so it may be useful for both macro and micro economists. Potential readers of the paper are innovation management researchers and practitioners, international economic relationship specialists, business strategists and administration and governments, predominantly from EU.

\section{Literature review}

For encompassing the big picture of the problem, the following topics should highlight the main participants playing a role in answering the research question. The topics are: Innovations as fundamental and the most powerful tool for economic growth;

Innovative and non-innovative enterprises as the main stakeholder in EU goals for achieving leading position in terms of innovativeness;

Importance of innovation for SMEs as they are the largest part of EU economy;

Some possible factors that might influence enterprises innovativeness and innovation performance.

\subsection{Innovations as fundamental and most powerful tool for eco- nomic growth}

Innovations are essential for economic growth and development (Feldman 2004). For business, improving and increasing innovativeness and the ability to develop innovations is the most substantial factor for growth (Damanpour 1991; Crossan and Apaydin 2010; Lopes et al. 2016). Consequentially, for countries, innovation is the most reliable tool for achieving growth. Even more, in time of crisis, innovation is the fundamental element of business development and survival in general (Sipos, Bizoi, and Ionescu 2014). Innovations claim to be the growth engine of modern economy and they ensure growth regardless of the economic environment (Tidd, Bessant, and Pavitt 1997; Sivak, Caplanova, and Hudson 2011). All these statements and idolization of the importance and power of innovation increase/raise the curiosity why the majority of enterprises are non-innovative after all.

For orientation of the readers of the research, we propose the following definition of innovation, without going deeper to prove it or to provide a literature review on the diversity of innovation's definitions:

"Innovation is the process of translating an idea or invention into a good or service that creates value or for which customers will pay. To be called an innovation, an idea must be replicable at an economical cost and must satisfy a specific need" (Yordanova 2017).

Following the definition of innovation as well as pursuing to focus on innovative and non-innovative enterprises, the paper uses the following definition of innovative and, respectively, of non-innovative enterprises:

"An innovative enterprise is one that has implemented technologically new or significantly improved products or processes or combinations of products and processes and performs successful innovation activities" (OECD 2005).

Respectively, non-innovative enterprise is an enterprise that has not implemented any kind of innovation during the researched period.

The Oslo Manual definition is used on purpose, however there are a lot of opener and wider definitions. The reason for that approach is the usage of data from Community Innovation Survey (CIS).

\subsection{Importance of innovation for SMEs as they are the largest part of EU economy}

Small and medium size enterprises are the largest number of enterprises in EU. Their share is around 99\% from all the registered enterprises in the Union, they are the major source for competitive advantage, economic growth and job creation (Borbás 2015; Luo, Wang, and Yang 2016).

A SME is an enterprise that belongs to one of the following types of enterprises: micro, small or medium. The categorization of the enterprises depends on the employees, the turnover and the balance sheet revenues of the enterprises. For micro enterprises the employees are under 10, less than 2 million euro turnover and assets below 2 million euro. For small enterprises: $<50 ;<10$ million euro; 10 million euro and for medium enterprises: $<250$; 50 million euro; 43 million euro (European Comission 2003).

Small and medium-sized enterprises are selected as an object of research, not only because they are the biggest share of enterprises, but also because they are considered to be the engine of the economy, the key for ensuring economic growth, innovation, job creation, and social integration in the EU (Airaksinen et al. 2015).

Small and medium-sized enterprises are the main focus of EU efforts to foster innovation. The main reason for it is that SMEs form the majority of all enterprises in Europe and can thus, be considered 
their economic backbone (Wymenga et al. 2011). These enterprises are responsible for more than $85 \%$ of all new jobs that were created between 2002 and 2012 (De Kok et al. 2011). This entrepreneurship developed in SMEs is the driver of economic growth (Wennekers et al. 2010). According to Bass and Ernst-Siebert (2007), SMEs seem to be the ideal vehicle to promote a sustainable innovation-based economic growth. Why SMEs are considered to be the engine of innovation development and progress in Europe? There are many evidences from literature sources and practice. According to Pavitt, Robson and Townsend (1987), SMEs are less bounded by routine and their management is much more likely to use and develop innovations. Scientists from KFW - Kreditanstalt für Wiederaufbau (2003), noted that the short and direct communication channels in SMEs additionally contribute to the implementation of innovation and its development. Many researches reach the conclusion that innovation is critical to enable SMEs to compete in domestic and global markets (Lee, Lee, and Pennings 2001; Hitt et al. 2001). There are evidences that SMEs and, especially, small enterprises with less than 50 employees are much more able to benefit from open innovation than larger enterprises but at the same time they are unable to build and participate in such an infrastructure, required for open innovation performance (Vahter, Love, and Roper 2014).

Even though there is no doubt for anyone that being an innovative enterprise is always essential for profit, sustainability and competitiveness (Rosenbusch, Brinckmann, and Bausch 2011), a lot of SMEs actually decide not to be. What are the reasons for that decision is under research in this study.

Khan and Manopichetwattana (1989), divided the non-innovative enterprises into the following types. The 'Silver Spoons' appeared to be surviving on past success; the 'Striving Stoics' displayed continuing managerial effort but were led by executives who had been at the helm far longer than average; and the 'Kismets' showed lesser competence and effort, were highly centralized, and were headed by executives tending more towards an external locus of control.

Innovation is especially important for industrial enterprises, being considered a key component in their success and in the extension of their capacity. The trend is confirmed by the increasing interest towards Industry 4.0 (Hoffmann, Bauersachs, and Prause 2016). That is why, this research is focus on industrial SMEs as they are amongst the priorities of EU and they are the main stakeholders of innovation trends.

\subsection{Innovative and non-innovative enterprises as main stakehold- ers of EU in terms of innovations}

The definition and clarifications, as well as differentiation between innovative and non-innovative enterprises has become even more interesting after evidence showing that innovative enterprises are able to sustain higher financial results than non innovative ones (Carvalho et al. 2016).

According to Hamel and Tennant (2015) 'truly' innovative enterprises possess the following five features: Employees who've been taught to think like innovators; A sharp, shared definition of innovation; Comprehensive innovation metrics; Accountable and capable innovation leaders; Innovation-friendly management processes. Baumgartner (2012) sets seven essential characteristics of innovative enterprises. These are: Unique and Relevant Strategy; Innovation Is a Means to Achieve Strategic Goals; Innovators Are Leaders; Innovators Implement; Failure Is an Option; Environment of Trust; Autonomy. For Lazonick (1993) an innovative enterprise is an organization that is able to transform the technological and market conditions into a result generating higher quality, lower cost or higher profit. Lewicka and Misterek (2013) concluded that innovative enterprises have the ability to quickly adapt to market changes by modifying their products or processes. However, after a thorough research, features that are usually matched to innovative enterprises are: market adaptiveness, continuous improvement and fast adaptation to changes.

Innovation specialists have summarized some of the most widespread reasons that make enterprises being non-innovative. These are: fear of failure, lack of money, lack of know-how, corporate bureaucracy, poor leadership, limited and non-spreading information, no recognition, bottom up thinking, handcuffing employees and no customer input (HLB 2017). Despite the importance of innovation for the success of enterprises (Fagerberg, Mowery, and Nelson 2004), statistical data gives us the insight that more than $50 \%$ of enterprises do not innovate (Eurostat 2017). From another perspective, SMEs are the main stakeholder in terms of innovation within EU (Radicic et al. 2014). That is why, they are selected as a subject of this research.

\subsection{Possible factors that might influence enterprises' innovativeness and enterprises' innovation performance and vice versa: to snag them}

There are many factors, circumstances and reasons that help, motivate or obligate enterprises to innovate. Therefore, there are a huge amount of research and papers examining that topic. Nevertheless, the factors, circumstances and reasons why enterprises are non-innovative are not so clear and they are not opposite to those that help enterprises to innovate. In this section of the paper, some of the possible factors and reasons that may influence enterprises' innovation performance and make these enterprises non-innovative ones are identified and analysed.

Innovation is an essential element for obtaining profit and taking leading market position. Innovation is also important for business performance and business development (de Jong, Marston, and Roth 2015). However, there are still controversial opinions about the relationship between innovation and financial performance of enterprises (Terra, Barbosa, and Bouzada 2015). Moreover, there are a lot of studies that examine the success factors of innovation projects (Kapsali 2011; Rajablu, Marthandan, and Yusoff 2014; Berchicci 2013; Sisodiya, Johnson, and Grégoire 2013). However, further study is necessary to uncover the factors that influence innovation performance and that make an enterprise being innovative or non-innovative. Knowing that factors and dependencies would be much easier for enterprises to handle, manage and use those factors, obstacles and circumstances in their advantage.

Generally, literature and research outline these three main factors that normally affect innovativeness of enterprises and enterprises' 
innovative performance: financial constraints, market competition and market demand (Blank 2013; da Silva, Oliveira, and de Moraes 2016; Cohen and Levin 1989).

\subsubsection{Financial constraints}

Financial constraints are logically amongst the first factors that pop up into mind when it comes to factors that influence enterprises' innovativeness. When summarizing financial constraints, many indicators could be mentioned: financial costs, cost of capital, required rate of return, tax policy, takeovers, difference in cost of internal funds (retained profits) and external funds (new equity or debt), cash flow dependencies, credits, capital markets and a lot more. Financial constraints, in terms of innovation, are usually connected to funding, financial markets, investments, cash-flow, profitability and scalability (Himmelberg and Petersen 1994; Hall, Mairesse, and Mulkay 2001).

Financial constraints that influence and harm innovations in SMEs are leverage, sensitiveness to cash flow and inability to maintain dividend payout (Crisóstomo, López-Iturriaga, and Vallelado 2011). As banks are one of the logical funding sources for SMEs and their innovation projects, researchers pointing out that asymmetric and unconvincing information characterizing innovation projects also troubles their development and the accessibility to bank loans. In particular, lack of financing is an obstacle relatively more important and frequently met by independent and smaller enterprises than for enterprises that belong to business groups or international conglomerates (Tamayo and Huergo 2017). Other problems, related to the difficult funding are: intangible assets, which are not desired by banks for a collateral (Williamson 1987); high risk; high uncertainty; unclear metrics; scalability requirements, that foster predominantly information and technology projects, etc. A widely spread and analysed financial constraint on company level is the credit/loan constraint. They are important especially to SMEs because credit requirements include indicators for employment, listed/non listed on the financial market, financial problems, index of financial pressure, profit margin, financial leverage, collateral/possession of the SME, cash holdings, total assets, etc. The research of Savignac (2006) estimates the impact of the financial constraints on the decision making process for innovations and his conclusion is that if financial constraints exist, they may significantly reduce the likelihood of an enterprise to undertake innovative projects. The specifics of innovative enterprises of investing and spending huge resources using intangible methods (as R\&D actually is) for the purpose of building intangible assets (as most of the innovations actually are) also contribute to the financial constraints that innovative enterprises encounter by not-working for their credit ratio (Stiglitz and Weiss 1981; Williamson 1987).

Small and medium size enterprises also face many obstacles in their attempts to access the credit market and according to Angilella and Mazzù (2015), these obstacles increase greatly if the SME is an innovative one. A study of Liang, McLean and Zhao (2013) found a clear, positive link between the financial system and meaningful innovation. The development of innovation contributes to financial performance of industrial SMEs, specifically, it is relevant to the customer needs and differentiating from competitors (Bigliardi 2013). Small and medium size enterprises need innovations and require innovative bank products to respond to these expanding needs (Yordanova 2013).

A research of KfW (2003) shows that some financial constraints exist due to asymmetric information between innovative enterprises and potential external investors. As a result, innovations in SMEs are financed to a greater extent/proportion by internal funds than compared to other firms.

Literature states that innovation performance can be measured and influenced by inputs - money spent on research and development (R\&D) or outputs - number of patents issued (Ahuja and Katila 2001; Henderson and Cockburn 1996). However, according to O’Regan, Ghobadian and Sims (2006), many SMEs have difficulties achieving successful innovation, despite having significant investment in R\&D. Therefore, financial support and intensive $R \& D$ are not primary factors for achieving innovative performance.

\subsubsection{Market competition and market demand as potential factors that hamper innovation in SMEs}

The connection between market competition and market demand towards innovative performance is a topic of interest from Schumpeter's time (Schumpeter 1934; Schumpeter 1942) and it is still a hot and debatable theme. Market demand and innovation in interaction are discussed by Mowery and Rosenberg (1979) even in the end of 1970th. Hashem and Ugur (2012) categorize the relationship between market and innovation as a conflict topic between different researchers because of the controversial opinions. Schumpeter interpreted market competition in terms of innovations as one of the drivers of innovations, but also as a destructive process in which effort, assets, and fortunes were continuously destroyed by innovation (Hovenkamp 2008).

Following the thesis of Mowery and Rosenberg (1979), Adner and Levinthal (2001) found that in the early technological development, enterprises are guided by customer needs and requirements instead of their own innovative vision. These researchers claim that the very moment after the market price and performance are met, technological innovation is driven by competition to attract technologically satisfied customers. Findings of Beneito, Rochina-Barrachina and Sanchis (2014) show that market competition is negatively affected by the innovation-related industrial property rights.

Market competition and market demand, in terms of innovation, both touch the topic of market concentration. Market concentration is especially important for the discussion of this research because of its object - the SMEs. The cross point between SMEs and market concentration is large enterprises market performance, respectively how SMEs cope with managing innovations in comparison with large enterprises in the highly competitive market and considering innovation as a key competitive tool for market leadership (Blagoev and Yordanova 2015). Market competition and market demand usually refer to active innovation performance and, generally, they boost innovation activities in enterprises (Kose and Topcu 2016). For Yusuf 
et. al. (2016), market demand is underestimated as a successful path for developing innovations and it is replaced by technology advancement and technology development. Market liberalization also has positive effects on enterprises innovative performance (Cambini, Caviggioli, and Scellato 2016).

However, each coin has two sides and these two factors can also harm the innovation performance of enterprises. How is that possible and how market competition and market demand may actually trouble innovations? According to Li and Kozhikode (2009) the increasing need of enterprises to respond to the market by quickly developing innovative products, effectively, intensively, frequently and at competitive cost, leads to lower innovation quality. It turns out that innovation is not an advancement or desire for development, but rather it is an essential and the sole tool for enterprises to survive and prosper in the current competitive and turbulent global environment. Other researchers pointed out that innovation performance has grown in the last decades as a result of consumers increasing demand for a variety of products and services (Schaarschmidt and Kilian 2014). Based on the statistical data of Eurostat (Eurostat 2014), the most important elements and factors that may hamper enterprises' innovation activities are: the market factor (the lack of information on markets or markets that are dominated by established enterprises), the technological factor (the lack of information on technology), the human resource factor (the lack of qualified personnel) and the relationship factor (the difficulty in finding cooperation partners for innovation). Findings of Szczygielski, Grabowski and Woodward (2017) show that the varieties of innovation are strongly sector-specific and tax-related, which in terms of EU industrial SMEs gives a reason for a lot of differentiations and constraints. Obstacles to innovation, in terms of market competition and market demand, come also from the processes of globalization and the difficulties for SMEs to collect specific market information about foreign markets, competition and customer demand (Iammarino et al. 2006).

The local market and internationalization factors can be seen from two perspectives: as an obstacle and as an advantage for innovative performance (Iammarino et al. 2006). The international factor and the globalization process are an obstacle for SMEs, but they are an advantage for multinational enterprises in their innovation activities, because technology transfer plays a more important role in innovation development and technical knowledge (Ietto-Gillies 2002; Dunning and Wymbs 1999).

\section{Methodology}

This paper intent to find out which are the factors that influence the percentage of non-innovative industrial SMEs. For this purpose, a cross-sectional study including several European countries is performed. Unlike the method of a longitudinal study which takes in consideration one and the same variables during a specified interval of time, the cross-sectional study takes in consideration the variables in a specific moment in time, in our case this is the moment between 2012 to 2014.
The statistic method that is used in the paper is a linear regression using SPSS software version 23. Regression defines a vast set of statistical techniques used to model relationships between variables and to predict the value of a dependent variable or response from a set of independent or predictive variables. It is expected that the results prove that there is a functional dependence between the dependent variable and one or more of the independent variables, that is, that the magnitude of the dependent variable is a function of the magnitude of one or more of the independent variables (Marôco 2014). The linear regression is selected as main method for answering the research question as the regression analysis belongs to the most important tools in statistical analysis for analysing dependent factors (Hron, Filzmoser, and Thompson 2012).

The percentage of non-innovative industrial SMEs is the dependent variable of the paper. We test as independent variables, four of the variables tested in the Community Innovation Survey (CIS) as reasons not to innovate. The independent variables of the study are in accordance with the performed literature review. All variables and respective acronyms (that are going to be used to facilitate the presentation of results) are listed in table 1 .

Table 1 Variables and acronyms

\begin{tabular}{l|l}
\hline Variable & Acronym \\
\hline Non-innovative enterprises & NON-INNOV \\
\hline $\begin{array}{l}\text { Enterprises for which the lack of inter- } \\
\text { nal finance was a highly important bar- } \\
\text { rier to innovate }\end{array}$ & INTERNAL_FINANCE \\
\hline $\begin{array}{l}\text { Enterprises for which the low market } \\
\text { demand was a highly important reason } \\
\text { to not innovate }\end{array}$ & LOW_MARKET_DEMAND \\
\hline $\begin{array}{l}\text { Enterprises for which the little market } \\
\text { competition was a highly important rea- } \\
\text { son to not innovate }\end{array}$ & $\begin{array}{l}\text { LITTLE_MARKET_COMPE- } \\
\text { TITION }\end{array}$ \\
\hline $\begin{array}{l}\text { Enterprises for which too much market } \\
\text { competition was a highly important bar- } \\
\text { rier to innovate }\end{array}$ & $\begin{array}{l}\text { HIGH_MARKET_COMPETI- } \\
\text { TION }\end{array}$ \\
\hline
\end{tabular}

The Data, used in the research was collected from the Eurostat website and it is based on CIS 2014 that studies innovation activities during the period 2012-2014. The Community Innovation Survey 2014 is a survey about innovation activities in enterprises, designed to provide information on the innovativeness of sectors by type of enterprises, on the different types of innovation and on various aspects of the development of an innovation, such as objectives, sources of information, public funding or expenditures. The CIS provides statistics broken down by countries, types of innovators, economic activities and size classes. The survey is currently carried out every two years across the European Union, EFTA countries and EU candidate countries. In order to ensure comparability across countries Eurostat developed a standard core questionnaire accompanied by a set of definitions and methodological recommendations. 
The collected data includes only SMEs from the industrial sector (as these enterprises are the main contributors to the innovative targets and policies of Europe). In the present study, the industrial SMEs are divided into two groups: the first group contains industrial SMEs with a number of employees between 50 and 249 and the second group consists of industrial SMEs with a number of employees between 10 and 49. The CIS data set allows extracting data for these two groups of SMEs and this paper is going to take advantage of that fact by comparing results between larger and smaller industrial SMEs. For the first group it was possible to obtain data for the following countries: Czech Republic, Estonia, France, Croatia, Italy, Cyprus, Latvia, Lithuania, Hungary, Austria, Poland, Romania, Slovakia, Iceland and Norway. For the second group, beside the previously mentioned countries, it was also possible to obtain data for Bulgaria, Greece and Portugal.
The total number of the SMEs that the data set contains and that take part in the research is 288859 SMEs with employees from 10 to 49 and 54412 SMEs with employees between 50 and 249. The total number of the enterprises in that data set is 343271 .

\section{Results}

In this section, the results from the linear regressions performed using SPSS, v. 23 are presented.

\subsection{Results for larger industrial SMEs}

First of all, the descriptive statistics of all variables are presented in table 2 .

Table 2 Descriptive Statistics

\begin{tabular}{|c|c|c|c|c|c|c|c|c|}
\hline & \multirow{2}{*}{$\frac{\mathrm{N}}{\text { Stat. }}$} & \multirow{2}{*}{$\frac{\text { Range }}{\text { Stat. }}$} & \multirow{2}{*}{$\frac{\text { Min }}{\text { Stat. }}$} & \multirow{2}{*}{$\frac{\text { Max }}{\text { Stat. }}$} & \multicolumn{2}{|c|}{ Mean } & \multirow{2}{*}{$\begin{array}{c}\text { Std. Dev. } \\
\text { Stat. }\end{array}$} & \multirow{2}{*}{$\begin{array}{c}\text { Var. } \\
\text { Stat. }\end{array}$} \\
\hline & & & & & Stat. & Std. Error & & \\
\hline NON-INNOV & 15 & 74,1 & 12,2 & 86,3 & 44,173 & 5,3055 & 20,5480 & 422,222 \\
\hline INTERNAL_FINANCE & 15 & 27,1 &, 0 & 27,1 & 8,827 & 1,9489 & 7,5481 & 56,974 \\
\hline LOW_MARKET_DEMAND & 15 & 18,6 & 5,4 & 24,0 & 13,533 & 1,7548 & 6,7963 & 46,190 \\
\hline LITTLE_MARKET_COMPETITION & 15 & 11,2 & 0,0 & 11,2 & 5,060 &, 7454 & 2,8871 & 8,335 \\
\hline HIGH_MARKET_COMPETITION & 15 & 13,7 & 0,0 & 13,7 & 4,767 & 1,0028 & 3,8838 & 15,084 \\
\hline $\begin{array}{l}\text { Valid N } \\
\text { (listwise) }\end{array}$ & 15 & & & & & & & \\
\hline
\end{tabular}

Results from the linear regression are in tables 3 to 5. Tables 6 and 7 present the results of the multicollinearity tests.

Table 3 Model Summary

\begin{tabular}{l|l|l|l|l}
\hline Model & R & R Square & $\begin{array}{l}\text { Adjusted R } \\
\text { Square }\end{array}$ & $\begin{array}{l}\text { Std. Error of the } \\
\text { Estimate }\end{array}$ \\
\hline 1 & $0,720 \mathrm{a}$ & 0,518 & 0,326 & 16,8715 \\
\hline
\end{tabular}

Predictors: (Constant), HIGH_MARKET_COMPETITION, LOW_ MARKET_DEMAND, LITTLE_MARKET_COMPETITION, INTERNAL_FINANCE
Table 4 ANOVA

\begin{tabular}{l|l|l|l|l|l}
\hline Model & Sum of Squares & df & Mean Square & F & Sig. \\
\hline Regression & 3064,624 & 4 & 766,156 & 2,692 &, $093^{\text {b }}$ \\
\hline Residual & 2846,485 & 10 & 284,649 & & \\
\hline Total & 5911,109 & 14 & & & \\
\hline
\end{tabular}

a. Dependent Variable: NON-INNOV

b. Predictors: (Constant), HIGH_MARKET_COMPETITION, LOW_MARKET_DEMAND, LITTLE_MARKET_COMPETITION, INTERNAL_FINANCE 
Table 5 Coefficients

\begin{tabular}{|c|c|c|c|c|c|c|c|c|}
\hline \multicolumn{2}{|c|}{ Model B } & \multicolumn{2}{|c|}{ Unstandardized Coefficients } & \multirow[t]{2}{*}{$\begin{array}{l}\text { Standardized } \\
\text { Coefficients }\end{array}$} & \multirow{3}{*}{\begin{tabular}{|l|}
$\mathbf{t}$ \\
3,712 \\
\end{tabular}} & \multirow{3}{*}{$\begin{array}{l}\text { Sig. } \\
\text { Tolerance } \\
0,004\end{array}$} & \multicolumn{2}{|c|}{$\begin{array}{l}\text { Collinearity } \\
\text { Statistics }\end{array}$} \\
\hline & & & & & & & & \\
\hline \multirow{4}{*}{1} & (Constant) & $\begin{array}{l}\text { Std. Error } \\
50,541\end{array}$ & \begin{tabular}{|l} 
Beta \\
13,614
\end{tabular} & & & & & \\
\hline & LITTLE_MARKET_COMPETITION & 3,428 & 1,812 & 0,482 & 1,891 & 0,088 & 0,743 & 1,347 \\
\hline & LOW_MARKET_DEMAND & $-2,180$ & 0,859 & $-0,721$ & $-2,537$ & 0,030 & 0,596 & 1,677 \\
\hline & HIGH_MARKET_COMPETITION & $-7,929$ & 3,840 & $-1,499$ & $-2,065$ & 0,066 & 0,091 & 10,937 \\
\hline
\end{tabular}

a. Dependent Variable: NON-INNOV

Table 6 Collinearity Diagnostics

\begin{tabular}{|c|c|c|c|c|c|c|c|c|}
\hline \multirow[b]{2}{*}{ Model } & \multirow[b]{2}{*}{ Dimension } & \multirow[b]{2}{*}{ Eigenvalue } & \multirow{2}{*}{$\begin{array}{c}\text { Condition } \\
\text { Index }\end{array}$} & \multicolumn{5}{|c|}{ Variance Proportions } \\
\hline & & & & (Constant) & $\begin{array}{c}\text { LITTLE_MARKET_ } \\
\text { COMPETITION }\end{array}$ & $\begin{array}{l}\text { INTERNAL_FI- } \\
\text { NANCE }\end{array}$ & $\begin{array}{c}\text { LOW_MAR- } \\
\text { KET_DEMAND }\end{array}$ & $\begin{array}{l}\text { HIGH_MARKET_ } \\
\text { COMPETITION }\end{array}$ \\
\hline \multirow{5}{*}{1} & 1 & 4,199 & 1,000 & 0,01 & 0,01 & 0,00 & 0,01 & 0,00 \\
\hline & 2 & 0,489 & 2,932 & 0,02 & 0,04 & 0,02 & 0,05 & 0,02 \\
\hline & 3 & 0,213 & 4,441 & 0,00 & 0,44 & 0,01 & 0,19 & 0,00 \\
\hline & 4 & 0,083 & 7,128 & 0,81 & 27 & 0,02 & 0,23 & 0,00 \\
\hline & 5 & 0,017 & 15,831 & 0,16 & ,24 & 0,95 & 0,52 & 0,97 \\
\hline
\end{tabular}

a. Dependent Variable: NON-INNOV

Table 7. Correlations

\begin{tabular}{l|l|l|l}
\hline \multicolumn{2}{c|}{} & INTERNAL_ & $\begin{array}{l}\text { H I G H } \\
\text { MAR KET_ } \\
\text { MINANCE } \\
\text { COMPETI- } \\
\text { TION }\end{array}$ \\
\hline \multirow{3}{*}{$\begin{array}{l}\text { INTER- } \\
\text { NAL_FI- }\end{array}$} & Pearson Correlation & 1 & $0,909^{* *}$ \\
\cline { 2 - 4 } \begin{tabular}{l} 
NANCE \\
\cline { 2 - 3 }
\end{tabular} & Sig. (2-tailed) & & 0,000 \\
\cline { 2 - 4 } $\begin{array}{l}\text { HIGH_- } \\
\text { MARKET_ } \\
\text { COMPE- } \\
\text { TITION }\end{array}$ & Pearson Correlation & $0,909^{* *}$ & 15 \\
\cline { 2 - 4 } & Sig. (2-tailed) & 0,000 & 15 \\
\cline { 2 - 4 } & N & 15 & 15 \\
\hline
\end{tabular}

**. Correlation is significant at the 0.01 level (2-tailed).

From table 3 it is possible to see that the $\mathrm{R} 2$ has a value of $51.8 \%$. This value measures the proportion of the total variability that is explain by the regression model so, $51.8 \%$ is not an excellent value but is acceptable when above 50\% (Marôco 2014).

On the other hand, the adjusted R2 - that increases only if an addition of a new variable leads to a better adjustment - as a value of $32.6 \%$, indicates that some of the variables might add little information to the model. This result might be due to multicollinearity between the variables INTERNAL_FINANCE and HIGH_MARKET_COMPETITION. This is proven by the existence of VIFs above 10 and tolerances near 1 (table 5), as well as an eigenvalue near zero, more precisely, 0.017 and a condition index with a value above 0.5 (table 6). In the table 7 it is possible to see that the correlation between both variables is 0.909 , which is another indicator of the presence of multicollinearity. It was attempted to achieve a different model eliminating one of these variables and testing the remaining significant variables but no satisfying model was obtained so, the analysis will continue including these two multicollinearity variables.

The model is only significant if we consider a confidence interval of $90 \%$ and, consequently, alpha values of 0.10 because ANOVA p-value is 0.093 (table 4).

In table 5, the four variables of the model are presented as well as their significance values. As expected, some variables have p-values above 0.5 (the most commonly use), more specifically, LITTLE_MARKET_ COMPETITION as a p-value of 0.088 and HIGH_MARKET_COMPETITION as a p-value of 0.066 .

The model equation that can be obtain from table 5 is:

NON-INNOVATIVE $=1.814$ INTERNAL_FINANCE -0.721 LOW_ MARKET_DEMAND + 0.482 LITTLE_MARKET_COMPETITION - 1.499 HIGH_MARKET_COMPETITION 


\subsection{Results for smaller industrial SMEs}

On first place, the descriptive statistics of all variables are presented in table 8.

Table 8 Descriptive Statistics

\begin{tabular}{|c|c|c|c|c|c|c|c|c|}
\hline & $\mathbf{N}$ & Range & Min. & Max. & Mean & & Std. Dev. & Var. \\
\hline & Stat. & Stat. & Stat. & Stat. & Stat. & Std. Error & Stat. & Stat. \\
\hline NON_INNOV & 18 & 43,7 & 45,5 & 89,2 & 64,761 & 3,4550 & 14,6584 & 214,870 \\
\hline INTERNAL_FINANCE & 18 & 35,6 & 0 & 35,6 & 12,250 & 2,1423 & 9,0892 & 82,613 \\
\hline LOW_MARKET_DEMAND & 18 & 22,0 & 6,8 & 28,8 & 14,161 & 1,4132 & 5,9958 & 35,950 \\
\hline HIGH_MARKET_COMPETITION & 18 & 19,7 & 0 & 19,7 & 7,117 & 1,1572 & 4,9094 & 24,103 \\
\hline Valid N (listwise) & 18 & & & & & & & \\
\hline
\end{tabular}

After several tests, the best possible model was obtained through a backward linear regression. In this method, the model is started with all ' $\mathrm{p}$ ' independent variables, and in the next step, a partial $\mathrm{F}$ statistic is calculated for each variable as if that variable were the last one to enter the model. The variable with the lowest value of $\mathrm{F}$ is compared with a critical value ( $\mathrm{F}$ removal), and if the partial $\mathrm{F}$ value is less than the F removal, that variable is removed from the model. In the next step, a new model with ' $\mathrm{p}-1$ ' independent variables is adjusted and the smallest partial F is compared with the F removal. This procedure continues until there are no variables in the model or until all variables present in the model have a partial $\mathrm{F}$ greater than $\mathrm{F}$ removal (Marôco 2014).

Results from the backward linear regression are presented in tables 9 to 12 and in this particular case, the backward procedure stopped in the third iteration (table 9).
Table 9 Model Summary

\begin{tabular}{l|l|l|l|l}
\hline Model & R & R Square & $\begin{array}{l}\text { Adjusted R } \\
\text { Square }\end{array}$ & $\begin{array}{l}\text { Std. Error of } \\
\text { the Estimate }\end{array}$ \\
\hline 1 &, $714^{\mathrm{a}}$ &, 510 &, 359 & 11,7376 \\
\hline 2 &, $713^{\mathrm{b}}$ &, 509 &, 404 & 11,3203 \\
\hline 3 &, $659^{\mathrm{c}}$ &, 434 &, 359 & 11,7376 \\
\hline
\end{tabular}

a. Predictors: (Constant), HIGH_MARKET_COMPETITION, LOW_MARKET_DEMAND, LITTLE_MARKET_COMPETITION, INTERNAL_FINANCE

b. Predictors: (Constant), LOW_MARKET_DEMAND, LITTLE_ MARKET_COMPETITION, INTERNAL_FINANCE

c. Predictors: (Constant), LOW_MARKET_DEMAND, INTERNAL_ FINANCE

Table 10 ANOVA (a)

\begin{tabular}{|c|c|c|c|c|c|c|}
\hline \multicolumn{2}{|c|}{ Model } & Sum of Squares & df & Mean Square & F & Sig. \\
\hline \multirow[t]{2}{*}{1} & Regression & 1861,745 & 4 & 465,436 & 3,378 &, $042^{\mathrm{b}}$ \\
\hline & Residual & 1791,037 & 13 & 137,772 & & \\
\hline \multirow[t]{2}{*}{2} & Regression & 1858,695 & 3 & 619,565 & 4,835 &, $016^{c}$ \\
\hline & Residual & 1794,088 & 14 & 128,149 & & \\
\hline \multirow[t]{3}{*}{3} & Regression & 1586,226 & 2 & 793,113 & 5,757 &, $014^{\mathrm{d}}$ \\
\hline & Residual & 2066,556 & 15 & 137,770 & & \\
\hline & Total & 3652,783 & 17 & & & \\
\hline
\end{tabular}

a. Dependent Variable: NON_INNOV

b. Predictors: (Constant), HIGH_MARKET_COMPETITION, LOW_MARKET_DEMAND, LITTLE_MARKET_COMPETITION, INTERNAL_FINANCE c. Predictors: (Constant), LOW_MARKET_DEMAND, LITTLE_ MARKET_COMPETITION, INTERNAL_FINANCE

d. Predictors: (Constant), LOW_MARKET_DEMAND, INTERNAL_FINANCE 
Table 11 Coefficients (a)

\begin{tabular}{|c|c|c|c|c|c|c|c|c|}
\hline \multicolumn{2}{|c|}{ Model B } & \multicolumn{2}{|c|}{ Unstandardized Coefficients } & \multirow[t]{2}{*}{$\begin{array}{l}\text { Standardized } \\
\text { Coefficients }\end{array}$} & \multirow{2}{*}{$\mathbf{t}$} & \multirow{2}{*}{$\begin{array}{l}\text { Sig. } \\
\text { Tolerance }\end{array}$} & \multicolumn{2}{|c|}{ Collinearity Statistics } \\
\hline & & Std. Error & Beta & & & & VIF & \\
\hline \multirow{5}{*}{1} & (Constant) & 76,282 & 8,744 & & 8,724 & 000 & & \\
\hline & INTERNAL_FINANCE & ,640 & ,861 & 397 & ,743 & 470 &, 132 & 7,556 \\
\hline & LOW_MARKET_DEMAND & $-1,885$ &, 540 &,- 771 & $-3,492$ & 004 & ,774 & 1,292 \\
\hline & LITTLE_MARKET_COMPETITION & 1,623 & 1,181 & ,305 & 1,375 & , 192 & ,768 & 1,302 \\
\hline & HIGH_MARKET_COMPETITION &,- 225 & 1,511 &,- 075 &,- 149 & ,884 & ,147 & 6,788 \\
\hline \multirow{4}{*}{2} & (Constant) & 75,768 & 7,748 & & 9,779 &, 000 & & \\
\hline & INTERNAL_FINANCE &, 523 & ,333 &, 324 & 1,570 & 139 & 823 & 1,215 \\
\hline & LOW_MARKET_DEMAND & $-1,869$ &, 510 &,- 764 & $-3,662$ & 003 & ,805 & 1,242 \\
\hline & LITTLE_MARKET_COMPETITION & 1,646 & 1,129 & 309 & 1,458 & , 167 & ,782 & 1,279 \\
\hline \multirow{3}{*}{3} & (Constant) & 79,933 & 7,468 & & 10,703 & 000 & & \\
\hline & INTERNAL_FINANCE & ,656 & ,332 & ,407 & 1,977 & 067 & ,890 & 1,123 \\
\hline & LOW_MARKET_DEMAND & $-1,639$ &, 503 &,- 670 & $-3,257$ & 005 & 890 & 1,123 \\
\hline
\end{tabular}

a. Dependent Variable: NON_INNOV

Table 12 Collinearity Diagnostics (a)

\begin{tabular}{|c|c|c|c|c|c|c|c|c|}
\hline \multirow[b]{2}{*}{ Model } & \multirow[b]{2}{*}{$\begin{array}{l}\text { Dimen- } \\
\text { sion }\end{array}$} & \multirow[b]{2}{*}{$\begin{array}{l}\text { Eigen- } \\
\text { value }\end{array}$} & \multirow[b]{2}{*}{$\begin{array}{l}\text { Condition } \\
\text { Index }\end{array}$} & \multicolumn{5}{|c|}{ Variance Proportions } \\
\hline & & & & (Constant) & $\begin{array}{l}\text { INTERNAL } \\
\text { FINANCE }\end{array}$ & $\begin{array}{l}\text { L } \quad \text { O W } \quad \text { - } \\
\text { MARKET } \text { DE- }_{-} \\
\text {MAND }\end{array}$ & $\begin{array}{l}\text { LITTLE_MARKET_ } \\
\text { COMPETITION }\end{array}$ & $\begin{array}{l}\text { HIGH_MARKET } \\
\text { COMPETITION }\end{array}$ \\
\hline \multirow[t]{5}{*}{1} & 1 & 4,443 & 1,000 & 0,00 & ,00 & ,01 & 01 & ,00 \\
\hline & 2 & 0,344 & 3,596 & 0,04 &, 04 & ,05 & 05 & ,04 \\
\hline & 3 & 0,111 & 6,313 & 0,15 & ,00 & ,15 & ,89 & ,00 \\
\hline & 4 & 0,080 & 7,471 & 0,55 & ,02 & ,68 &, 00 & ,02 \\
\hline & 5 & 0,022 & 14,145 & 0,25 & ,93 & ,12 & ,05 & ,93 \\
\hline \multirow[t]{4}{*}{2} & 1 & 3,592 & 1,000 & 0,01 & ,02 & ,01 & ,01 & \\
\hline & 2 & 0,224 & 4,005 & 0,07 & 96 &, 04 & ,03 & \\
\hline & 3 & 0,110 & 5,721 & 0,12 & ,01 & ,19 & 96 & \\
\hline & 4 & 0,075 & 6,936 & 0,80 & 01 & ,76 & 01 & \\
\hline \multirow[t]{3}{*}{3} & 1 & 2,708 & 1,000 & 0,02 &, 04 & ,02 & & \\
\hline & 2 & 0,218 & 3,527 & 0,12 & ,96 & ,08 & & \\
\hline & 3 & 0,075 & 6,015 & 0,86 & 01 & 91 & & \\
\hline
\end{tabular}

a. Dependent Variable: NON_INNOV

The obtained R2 is 0.434 and the adjusted R2 is 0.359 (table 9). The obtain model is significant with a p-value of 0.014 (table 10) and again, the model is only significant for alpha values of $10 \%$ since INTERNAL_FINANCE has a p-value of 0.067 (table 11).

From the analysis of the tables 11 and 12 , it is possible to be concluded that there are no multicollinearity problems. In the table 11 it is visible that the model has only two statistical significant variables (INTERNAL_FINANCE and LOW_MARKET_DEMAND) and that the obtained model equation is:
NON-INNOVATIVE $=0.407$ INTERNAL_FINANCE -0.670 LOW MARKET_DEMAND

\section{Discussion}

Results from the applied methodology, in the case of EU industrial SMEs with a number of employees' between 50 and 249, suggest that lack of internal finance and little market competition do not stimulate enterprises to be innovative. On the other hand, high market competition is a driven force for innovation, which is all in accordance with the literature review and especially with the conclusions of Tamayo and Huergo (2017). 
The most surprising result is that a low market demand does not contribute to an increase in the percentage of non-innovative enterprises. The literature review suggested that a high market demand (it wasn' $t$ possible to obtain data for this variable in CIS), contributes to increase innovation performance within enterprises (this only makes sense in high demand and at the same time high competitive markets), but this study demonstrates that a low market demand has also a positive effect on innovation. This result indicates that enterprises that are inserted in markets with low demand, do feel the need to be innovative in order to create new markets and, consequently, new demand ensuring their survival.

Although there is a multicollinearity problem, it does not seem to affect the results since the variables affected by multicollinearity problems are in accordance with the literature review and the unique surprising one is confirmed by the group of the smaller SMEs. Additionally, multicollinearity does not affect the ability to extrapolate the results in different samples.

Amongst the group of smaller SMEs and, as expected, the lack of internal finance is the main obstacle to innovation. The results from the analysis of this group also confirm that a low market demand generally stimulates innovation. The difference to the group of larger SMEs is that market competition has no effect on these enterprises. This fact may lead us to suppose that this group of smaller SMEs are more dependent of proximity and national markets and that they are not very active in international markets. On the contrary, larger SMEs are sensitive to market competition because they are more present in international markets. This may also lead us to conclude that there is a correlation between size and internationalization.

\section{Conclusion}

The number of non-innovative enterprises within $\mathrm{EU}$ is a topic of great interest for researchers, national governments and practitioners. The main reason for it is the belief that innovations would transform EU's economy onto a superior level and would facilitate converting it to the leading economy in the world. Surprisingly, after more than 10 years of great support and target activities in direction of boosting innovative activities of enterprises of EU member countries, statistics show that less than $50 \%$ of the enterprises are actually innovative. Results are even more frightening for SMEs and especially for industrial SMEs. At the same time, this kind of enterprises are considered to be the key cornerstone for innovating the economy and achieving the main targets of the Union. The question "Why enterprises say "no" to innovations" is meaningful for the governments of the EU countries and for the management of SMEs. By answering it, governments would know what are the factors that hamper and support innovative performance on micro level for the whole Union and how they can influence that performance. The research question and the findings of the study are especially important for policy implications and policy alignment to the targets of the Union.

Results of the study leads us to conclude that the lack of market demand do not influence the number and the share of non-innovative enterprises. This result is surprisingly, as market demand influences innovativeness and the number of innovative enterprises, it was expected that the lack of it could affect the number of non-innovative enterprises. A conclusion that can be made from this finding is that innovative enterprises, which decide to follow the path of innovations, find innovative solutions and do innovations, no matter of the existing of market demand (they create breakthrough innovations; create demand; switch fast between innovative products and processes; pivot if the market does not respond to their expectations, etc.). The next question on the agenda that comes naturally from the study's finding is - are SMEs following market trends and market demand to create an idea of what kind of innovations to do? Is that the answer for the actual low percentage of radical and breakthrough innovations? These last questions set the research direction for our next research: what are the real obstacles for SMEs to create breakthrough and radical innovations and what does the market demand have in common with that?

Limitations from this research result from the fact that we use a cross section study with a pre-defined period, this means that a radical change that have may occur in the meantime could change results.

\section{About authors:}

Nuno Carvalho has a graduation in Economics and another in Administration. He has a Master's degree in Management with specialization in Entrepreneurship and Innovation and is currently a $\mathrm{PhD}$ student in Management and works as project manager at University of Coimbra. His research interests are innovation, entrepreneurship, knowledge management and e-Government.

Zornitsa B. Yordanova has received her PhD in the area of Business Innovations management in the University of National and World economy, Sofia, Bulgaria and now she is an Assistant Professor there. Her research interest includes innovation management, business innovations, project management, innovation projects, enterprise management, management information systems and enterprise software. She is also certified as $\mathrm{PMP}^{\star}$ and $\mathrm{CSM}^{\star}$ in the area of project management.

\section{References}

Adner, Ron, and Daniel Levinthal. 2001. "Demand Heterogeneity and Technology Evolution: Implications for Product and Process Innovation." Management Science 47 (5). INFORMS: 611-28.

Ahuja, Gautam, and Riitta Katila. 2001. “Technological Acquisitions and the Innovation Performance of Acquiring Firms: A Longitudinal Study." Strategic Management Journal 22 (3). Wiley Online Library: 197-220.

Airaksinen, Aarno, Henri Luomaranta, Pekka Alajääskö, and Anton Roodhuijzen. 2015. "Dependent and Independent SMEs and Large Enterprises." Eurostat Statistics on Small and Medium-Sized Enterprises. http://ec.europa.eu/eurostat/statistics-explained/index.php/Statistics_on_small_and_medium-sized_enterprises. 
Angilella, Silvia, and Sebastiano Mazzù. 2015. "The Financing of Innovative SMEs: A Multicriteria Credit Rating Model." European Journal of Operational Research 244 (2). Elsevier: 540-54.

Bailey, Ian. 2014. "Institutional Complexity in European Union Climate Innovation: European and National Experiences with off-Shore Renewable Energy." In Climate Innovation, 235-54. Springer.

Bamford, Jim, and David Ernst. 2002. "McKinsey on Finance." https://www.google.pt/url? sa=t\&rct=j\&q=\&esrc=s\&source=web $\& c d=2 \& v e d=0$ ahUKEwiL5a6GmY7TAhUHRhQKHZb9DdwQF gggMAE\&url=http\%3A\%2F\%2Fwww.mckinsey.com\%2Fclient_ service\%2Fcorporate_finance\%2Flatest_thinking\%2Fmckinsey_on_ finance $\% 2$ F $\% 2$ Fmedia $\% 2$ FFA 13 CECC4AA5422AB7822C.

Bass, Hans-Heinrich, and Robert Ernst-Siebert. 2007. "SME in Germany's Maritime Industry: Innovation, Internationalisation and Employment." International Journal of Globalisation and Small Business 2 (1). Inderscience Publishers: 19-33.

Baumgartner, Jeffrey. 2012. "The Seven Essential Characteristics of Innovative Enterprises." Innovation Management. http://www.innovationmanagement.se/2012/12/18/the-seven-essential-characteristics-of-innovative-enterprises/.

Beneito, Pilar, Maria Engracia Rochina-Barrachina, and Amparo Sanchis. 2014. "Patents, Competition, and Firms' Innovation Incentives." Industry and Innovation 21 (4). Taylor \& Francis: 285-309.

Bentivoglio, Deborah, Elisa Giampietri, and Adele Finco. 2016. "THE NEW EU INNOVATION POLICY FOR FARMS AND SMEs' COMPETITIVENESS AND SUSTAINABILITY: THE CASE OF CLUSTER AGRIFOOD MARCHE IN ITALY." Calitatea 17 (S1). Romanian Society for Quality Assurance: 57.

Berchicci, Luca. 2013. “Towards an Open R\&D System: Internal R\&D Investment, External Knowledge Acquisition and Innovative Performance." Research Policy 42 (1). Elsevier: 117-27.

Bigliardi, Barbara. 2013. “The Effect of Innovation on Financial Performance: A Research Study Involving SMEs.” Innovation 15 (2). Taylor \& Francis: 245-55.

Blagoev, Dimitar, and Zornitsa Yordanova. 2015. "Company Innovative Leadership Model." Economic Alternatives, no. 2. University of National and World Economy, Sofia, Bulgaria: 5-16.

Blank, Steve. 2013. "Why Big Enterprises Can't Innovate." Steve Blank. https://steveblank.com/2013/02/23/why-big-enterprises-cant-innovate/.

Borbás, Lászlo. 2015. "The Role of SMEs in the European Entrepreneurship Policy." Volume of Management, Enterprise and Benchmarking in the 21st Century II. \{Ó\}buda University, Keleti Faculty of Business and Management, 71-88.

Cambini, Carlo, Federico Caviggioli, and Giuseppe Scellato. 2016.
"Innovation and Market Regulation: Evidence from the European Electricity Industry." Industry and Innovation 23 (8). Taylor \& Francis: $734-52$.

Carvalho, Nuno, Luisa Carvalho, and Sandra Nunes. 2015. "A Methodology to Measure Innovation in European Union through the National Innovation System." International Journal of Innovation and Regional Development 6 (2). Inderscience Publishers (IEL): 159-80.

Carvalho, Nuno, and Rui Pedro Lourenço. 2017. "E-Rulemaking: Tecnologias Utilizadas E Resultados Alcançados.” In ATAS Confer $\{\hat{e}\}$ ncia APSI, 16:336-49.

Chobanova, Habil Rossitsa. 2016. "RESEARCH AND INNOVATION IN BULGARIA'S DEVELOPMENT: BEFORE A POLICY DILEMMA.” Journal of Vietnam's Socio-Economic Development 87 (October): 69-80.

Cohen, Wesley M, and Richard C Levin. 1989. "Empirical Studies of Innovation and Market Structure." Handbook of Industrial Organization 2. Elsevier: 1059-1107.

Comission, European. 2017. "EU Industrial Policy." Internal Markets, Industry, Entrepreneurship and SMEs. https://ec.europa.eu/growth/ industry/policy/eu_en.

Crisóstomo, Vicente Lima, Félix Javier López-Iturriaga, and Eleuterio Vallelado. 2011. "Financial Constraints for Innovation in Brazil." Latin American Business Review 12 (3). Taylor \& Francis: 165-85.

Crossan, Mary M, and Marina Apaydin. 2010. "A Multi-Dimensional Framework of Organizational Innovation: A Systematic Review of the Literature." Journal of Management Studies 47 (6). Wiley Online Library: 1154-91.

da Silva, Fabiana Matos, Edson Aparecida de Araujo Querido Oliveira, and Marcela Barbosa de Moraes. 2016. "Innovation Development Process in Small and Medium Technology-Based Enterprises." RAI Revista de Administra $\{c\}\{\tilde{a}\}$ o E Inova $\{c\}\left\{\{a\}_{0} 13\right.$ (3). Elsevier: 176-89.

Damanpour, Fariborz. 1991. "Organizational Innovation: A MetaAnalysis of Effects of Determinants and Moderators." Academy of Management Journal 34 (3). Academy of Management: 555-90.

de Carvalho, Antonio Oliveira, Ivano Ribeiro, Claudia Brito Silva Cirani, and Renato Fabiano Cintra. 2016. "Organizational Resilience: A Comparative Study between Innovative and Non-Innovative Enterprises Based on the Financial Performance Analysis." International Journal of Innovation 4 (1). Universidade Nove de Julho (UNINOVE), PPGA: 58.

de Jong, Marc, Nathan Marston, and Erik Roth. 2015. “The Eight Essentials of Innovation.” McKinsey Quarterly 1995.

De Kok, Jan, Paul Vroonhof, Wim Verhoeven, Niek Timmermans, Ton Kwaak, Jacqueline Snijders, and Florieke Westhof. 2011. "Do SMEs Create More and Better Jobs." Report Prepared by EIM for the European Commission DG Enterprise and Industry, Brussels, European Commission. 
Di Cataldo, Marco, and Andrés Rodriguez-Pose. 2017. "What Drives Employment Growth and Social Inclusion in the Regions of the European Union?" Regional Studies. Routledge, 1-20.

Dunning, John H, and Clifford Wymbs. 1999. "10 The Geographical Sourcing of Technology-Based Assets by Multinational Enterprises." Innovation Policy in a Global Economy. Cambridge University Press, 184.

Elert, Niklas, Magnus Henrekson, and Mikael Stenkula. 2017. "Institutional Reform for Enhanced Innovation and Entrepreneurship: An Agenda for Europe."

European Comission. 2003. "Commission Recommendation of 6 May 2003 Concerning the Definition of Micro, Small and MediumSized Enterprises." Official Journal of the European Union 46: 36-41.

EUROPEAN UNION. 2007. “Treaty of Lisbon." EU law and publications. http://eur-lex.europa.eu/legal-content/EN/ TXT/?uri=celex\%3A12007L\%2FTXT.

Eurostat. 2014. "Results of the Second Community Innovation Survey (CIS2)." Reference Metadata in Euro SDMX Metadata Structure (ESMS). http://ec.europa.eu/eurostat/cache/metadata/en/inn_cis2_esms.htm.

Eurostat. 2016. "R \& D Expenditure." Eurostat Statistics Explained. http://ec.europa.eu/eurostat/statistics-explained/index.php/ R_\%26_D_expenditure.

Eurostat. 2017. "Innovation Statistics." Eurostat Statistics Explained. http://ec.europa.eu/eurostat/statistics-explained/index.php/Innovation_statistics.

Fagerberg, Jan, David C Mowery, and Richard R Nelson. 2004. "The Oxford Handbook of Innovations." Fagerberg, DC Mowey.

Feldman, Maryann. 2004. “The Significance of Innovation.” Rotman School of Management, University of Toronto, 1-14.

Fougère, Martin, Beata Segercrantz, and Hannele Seeck. 2017. "A Critical Reading of the European Union's Social Innovation Policy discourse:(Re) Legitimizing Neoliberalism." Organization. SAGE Publications Sage UK: London, England, 1350508416685171.

Hall, B H, J Mairesse, and B Mulkay. 2001. "Firm Level Investment and R\&D in France and in the United States." Investing Today for the World of Tomorrow, Springer Verlag.

Hamel, G, and M Tennant. 2015. “The 5 Requirements of a Truly Innovative Company." Harvard Business Review 27.

Hashem, Nawar, and Mehmet Ugur. 2012. "Market Concentration, Corporate Governance and Innovation: Partial and Combined Effects in US-Listed Firms."

Henderson, Rebecca, and Iain Cockburn. 1996. "Scale, Scope, and Spillovers: The Determinants of Research Productivity in Drug Discovery." The Rand Journal of Economics. JSTOR, 32-59.
Himmelberg, Charles P, and Bruce C Petersen. 1994. "R \& D and Internal Finance: A Panel Study of Small Firms in High-Tech Industries." The Review of Economics and Statistics. JSTOR, 38-51.

Hitt, Michael A, R Duane Ireland, S Michael Camp, and Donald L Sexton. 2001. "Strategic Entrepreneurship: Entrepreneurial Strategies for Wealth Creation.” Strategic Management Journal 22 (6-7). Wiley Online Library: 479-91.

HLB. 2017. “Top Ten Reasons Why Your Company Is Not Innovative.” http://www.hlb.com/design-news/top-ten-reasons-your-company-is-not-innovative.

Hoffmann, Matthias, Andrea Bauersachs, and Andreas Prause. 2016. "Method for Mounting Adjustable Mechanism for Motor Vehicle.” Google Patents.

Hovenkamp, Herbert J. 2008. "Schumpeterian Competition and Antitrust."

Hron, Karel, Peter Filzmoser, and Katherine Thompson. 2012. "Linear Regression with Compositional Explanatory Variables." Journal of Applied Statistics 39 (5). Taylor \& Francis: 1115-28.

Iammarino, Simona, F Sanna-Randacio, Maria Savona, and A T Tavares. 2006. "Obstacles to Innovation and Multinational Firms in the Italian Regions: Firm-Level Evidence from the Third Community Innovation Survey." Multinationals, Clusters and Innovation: Does Public Policy Matter. Springer, 63-83.

Ietto-Gillies, Grazia. 2002. Transnational Corporations: Fragmentation amidst Integration. Routledge.

Janger, Jürgen, Torben Schubert, Petra Andries, Christian Rammer, and Machteld Hoskens. 2017. "The EU 2020 Innovation Indicator: A Step Forward in Measuring Innovation Outputs and Outcomes?" Research Policy 46 (1). Elsevier: 30-42.

Kapsali, Maria. 2011. "Systems Thinking in Innovation Project Management: A Match That Works." International Journal of Project Management 29 (4). Elsevier: 396-407.

KfW, Creditreform. 2003. "IfM Bonn, ZEW Und DtA (2003), MittelstandsMonitor 2003.” J\{ä\}hrliher Bericht Zu Konjunktur-Und Strukturfragen Kleiner Und Mittlerer Unternehmen. Ver\{ö\}ffentlicht Am 10.

Khan, Arshad, and Veerachai Manopichetwattana. 1989. "Innovative and Noninnovative Small Firms: Types and Characteristics." Management Science 35 (5). INFORMS: 597-606.

Khan, Zaheer, Yong Kyu Lew, and Pervaiz Akhtar. 2016. “The Influence of Industrial Policy and National Systems of Innovation on Emerging Economy Suppliers' Learning Capability." Industry and Innovation 23 (6). Taylor \& Francis: 512-30.

Kose, Can, and Ulvi Cenap Topcu. 2016. "INNOVATION MEASUREMENT REVISITED: COMPARISON OF THREE MAIN MEASURES." In Economic and Social Development (Book of Proceedings), 18th International Scientific Conference on Economic and Social, 245. 
Lazonick, William. 1993. Business Organization and the Myth of the Market Economy. Cambridge University Press.

Lee, Choonwoo, Kyungmook Lee, and Johannes M Pennings. 2001. "Internal Capabilities, External Networks, and Performance: A Study on Technology-Based Ventures." Strategic Management Journal 22 (6-7). Wiley Online Library: 615-40.

Lewandowska, Małgorzata Stefania, and Marzenna Anna Weresa. 2016. "Effects of Additionality from Public Financial Support to Innovation in the European Union: Poland and Selected Other Member States Compared." COMPETITIVENESS REPORT 2016, 193.

Lewicka, Beata, and Wojciech Misterek. 2013. "Features of an Innovative Company in the Opinion of the Business Entities and the $\mathrm{Bu}-$ siness Environment Institutions." In Active Citizenship by Knowledge Management \& Innovation: Proceedings of the Management, Knowledge and Learning International Conference 2013, 577-84.

Li, Jiatao, and Rajiv Krishnan Kozhikode. 2009. "Developing New Innovation Models: Shifts in the Innovation Landscapes in Emerging Economies and Implications for Global R\&D Management." Journal of International Management 15 (3). Elsevier: 328-39.

Liang, Claire Y C, David McLean, and Mengxin Zhao. 2013. "US Financial Markets Growth and the Real Economy."

Lopes, Ana Paula Vilas Boas Viveiros, Kumiko Oshio Kissimoto, Mario Sergio Salerno, Marly Monteiro de Carvalho, and Fernando José Barbin Laurindo. 2016. "INNOVATION MANAGEMENT: A SYSTEMATIC LITERATURE ANALYSIS OF THE INNOVATION MANAGEMENT EVOLUTION.” Brazilian Journal of Operations \& Production Management 13 (1): 16-30.

Luo, Pengfei, Huamao Wang, and Zhaojun Yang. 2016. "Investment and Financing for SMEs with a Partial Guarantee and Jump Risk." European Journal of Operational Research 249 (3). Elsevier B.V.: 116168. doi:10.1016/j.ejor.2015.09.032.

Marôco, João. 2014. Análise Estatística Com O SPSS Statistics. $6^{\mathrm{a}}$. ReportNumber, Lda.

Mowery, David, and Nathan Rosenberg. 1979. “The Influence of Market Demand upon Innovation: A Critical Review of Some Recent Empirical Studies." Research Policy 8 (2). Elsevier: 102-53.

O’Regan, Nicholas, Abby Ghobadian, and Martin Sims. 2006. "Fast Tracking Innovation in Manufacturing SMEs." Technovation 26 (2). Elsevier: 251-61.

OECD. 2005. "Oslo Manual: Guidelines for Collecting and Interpreting Innovation Data.” OECD Publising. http://www.oecd.org/docum ent/23/0,3746,en_2825_30453906_35595607_1_1_1_1,00.html.

Pavitt, Keith, Michael Robson, and Joe Townsend. 1987. "The Size Distribution of Innovating Firms in the UK: 1945-1983.” The Journal of Industrial Economics. JSTOR, 297-316.
Radicic, Dragana, Geoff T Pugh, Hugo Hollanders, and René Wintjes. 2014. "The Impact of Innovation Support Programmes on SME Innovation in Traditional Manufacturing Industries: An Evaluation for Seven EU Regions."

Rajablu, Mahmoud, Govindan Marthandan, and Wan Fadzilah Wan Yusoff. 2014. "Managing for Stakeholders: The Role of StakeholderBased Management in Project Success." Asian Social Science 11 (3): 111.

Rosenbusch, Nina, Jan Brinckmann, and Andreas Bausch. 2011. "Is Innovation Always Beneficial? A Meta-Analysis of the Relationship between Innovation and Performance in SMEs." Journal of Business Venturing 26 (4). Elsevier: 441-57.

Savignac, Frédérique. 2006. "The Impact of Financial Constraints on Innovation: Evidence from French Manufacturing Firms." Centre d'Economie de la Sorbonne-UMR 8174.

Schaarschmidt, Mario, and Thomas Kilian. 2014. "Impediments to Customer Integration into the Innovation Process: A Case Study in the Telecommunications Industry." European Management Journal 32 (2). Elsevier: $350-61$.

Schumpeter, Joseph. 1934. The Theory of Economic Development: An Inquiry into Profits, Capital, Credit, Interest, and the Business Cycle. Vol. 55. Transaction publishers.

Schumpeter, Joseph. 1942. Capitalism, Socialism and Democracy. Edited by Hamper Brother. New York.

Sipos, Gabriela Lucia, Gabriel Bizoi, and Alin Ionescu. 2014. “The Impact of Hampering Innovation Factors on Innovation Performance-European Countries Case." Procedia-Social and Behavioral Sciences 124. Elsevier: $415-24$.

Sisodiya, Sanjay R, Jean L Johnson, and Yany Grégoire. 2013. "Inbound Open Innovation for Enhanced Performance: Enablers and Opportunities." Industrial Marketing Management 42 (5). Elsevier: 836-49.

Sivak, Rudolf, Anetta Caplanova, and John Hudson. 2011. “The Impact of Governance and Infrastructure on Innovation." PostCommunist Economies 23 (2): 203-17. doi:10.1080/14631377.201 1.570050 .

Stiglitz, Joseph E, and Andrew Weiss. 1981. "Credit Rationing in Markets with Imperfect Information." The American Economic Review 71 (3). JSTOR: 393-410.

Szczygielski, Krzysztof, Wojciech Grabowski, and Richard Woodward. 2017. "Innovation and the Growth of Service Enterprises: The Variety of Firm Activities and Industry Effects." Industry and Innovation 24 (3). Taylor \& Francis: 249-62.

Tamayo, Mery Patricia, and Elena Huergo. 2017. "Determinants of Internal and External R\&D Offshoring: Evidence from Spanish Firms." Industry and Innovation 24 (2). Taylor \& Francis: 143-64. 
Terra, Natália Mendonça, Jose Geraldo Pereira Barbosa, and Marco Aurélio Carino Bouzada. 2015. "A Influência Da Inovação Em Produtos E Processos No Desempenho de Empresas Brasileiras." RAI Revista de Administração E Inovação 12 (3). Elsevier: 183-208.

Tidd, Joseph, John R Bessant, and Keith Pavitt. 1997. Managing Innovation: Integrating Technological, Market and Organizational Change. Vol. 4. Wiley Chichester.

Vahter, Priit, James H Love, and Stephen Roper. 2014. "Openness and Innovation Performance: Are Small Firms Different?" Industry and Innovation 21 (7-8). Taylor \& Francis: 553-73.

Wennekers, Sander, Andre Van Stel, Martin Carree, Roy Thurik, and others. 2010. "The Relationship between Entrepreneurship and Economic Development: Is It U-Shaped?” Foundations and Trends $\left\{{ }^{\circledR}\right\}$ in Entrepreneurship 6 (3). Now Publishers, Inc.: 167-237.

Williamson, Stephen D. 1987. "sCostly Monitoring, Loan Contracts, and Equilibrium Market Rationingt." The Quarterly Journal of Economics, February 135: 145.
Wymenga, Paul, V Spanikova, A Barker, J Konings, and E Canton. 2011. "EU SMEs in 2012: At the Crossroads." Annual Report on Small and Medium-Sized Enterprises in the EU 12.

Yordanova, Zornitsa. 2013. "Innovative Business Bank Products." Trakia Journal of Sciences 11 (1): 5-13.

Yordanova, Zornitsa. 2017. "Lean Startup Method Hampers Breakthrough Innovations and Company's Innovativeness." International Journal of Innovation and Technology Management.

Yusuf, Muhammad Fakhrul, Hasbullah Ashari, Mohd Rizal Razalli, and Rashidah Ramle. 2016. "Environmental Technological Innovation and Market Demand: Is Market Orientation a Missing Link?" Researchgate.

Zhelev, Paskal. 2014. "International Technology Transfer to Bulgaria after Its European Union Accession.” Economic Alternatives, no. 3. University of National and World Economy, Sofia, Bulgaria: 83-94. 